\title{
Significance and Disturbance Study of Devonshire Beach-Lesser Slave Lake Provincial Park
}

Submitted to:

Parks and Protected Areas Division

Room 1301 Box 18, Provincial Building

$10320-99^{\text {th }}$ Street

Grande Prairie, AB

Submitted by:

Geowest Environmental Consultants Ltd. Suite 203, 4208 - 97 Street

Edmonton, AB T6E $5 Z 9$

September, 2004
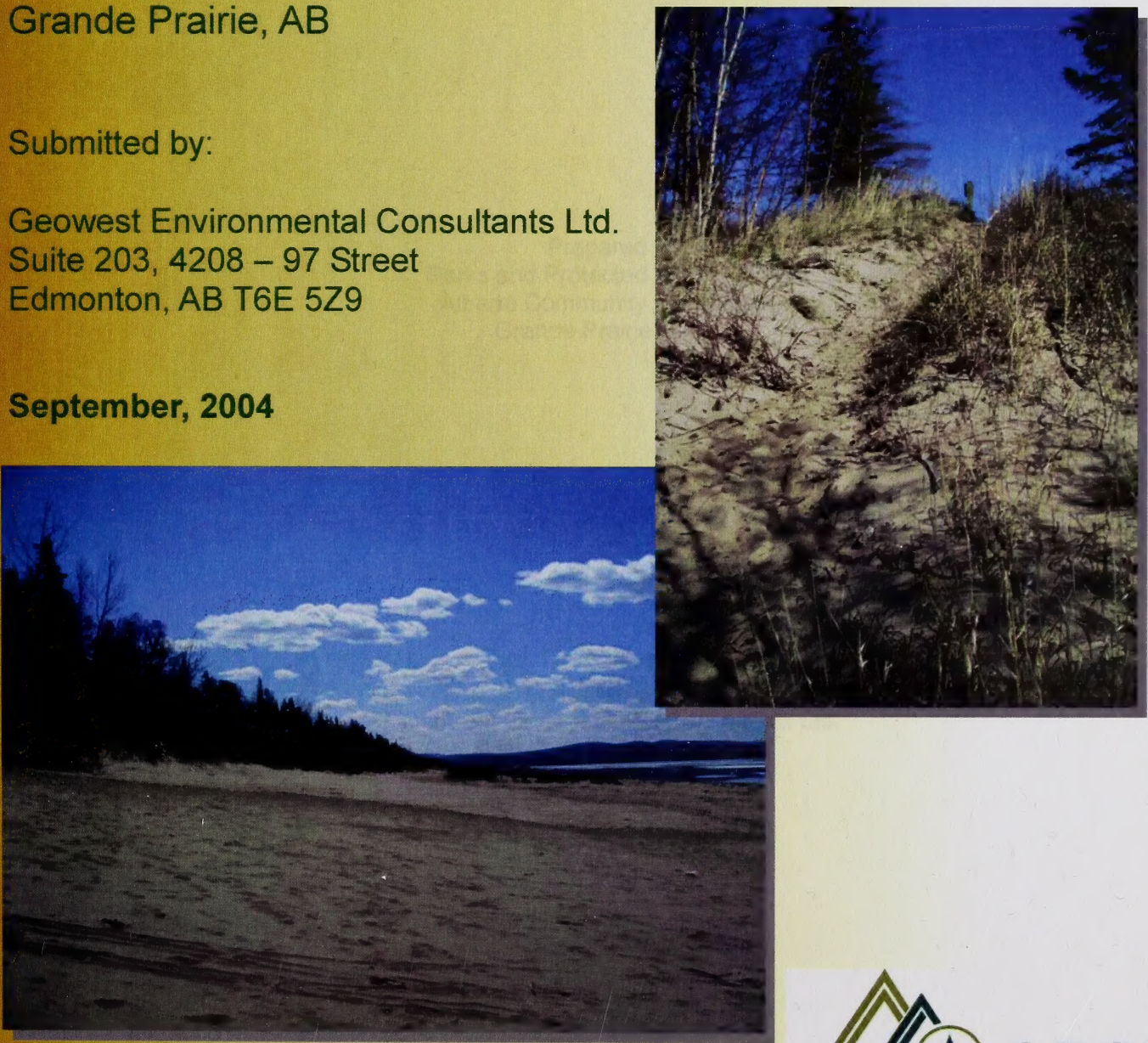
Digitized by the Internet Archive in 2016 


\title{
Significance and Disturbance Study of Devonshire Beach - Lesser Slave Lake Provincial Park
}

\author{
Prepared for: \\ Parks and Protected Areas Division \\ Alberta Community Development \\ Grande Prairie, Alberta
}

\author{
Prepared by: \\ Geowest Environmental Consultants Ltd. \\ Suite 203, 4208 - 97 Street \\ Edmonton, Alberta \\ Canada \\ T6E $5 Z 9$
}

September 2004 





\section{Executive Summary}

Alberta Community Development, Parks and Protected Areas Division, is preparing a management plan for Devonshire Beach along with the Town of Slave Lake, the Municipal District of Lesser Slave River \#124, and other stakeholders. Alberta Community Development, Parks and Protected Areas, retained Geowest Environmental Consultants to conduct two biophysical studies for Devonshire Beach including:

- An assessment of the beach ridge to determine its level of significance and disturbance, and

- A vegetation inventory and rare plant survey.

Each component is closely linked, as the vegetation growing in the area is influenced by the presence of the beach ridge, and the vegetation influences the development of the beach ridge. This report details the findings of the beach ridge significance study.

A thorough literature search was conducted, during which gaps in baseline information were detected. To further clarify the significance of the beach ridge and to assist in developing potential mitigation measures, a questionnaire was designed and conducted. The questionnaire was designed to fill in some of the information gaps. The questionnaire was sent out to pertinent individuals with knowledge of Devonshire beach and included local people from Slave Lake, First Nations, resource planners, government employees and academics. The questionnaires yielded vital current and historical information related to the uses of the beach ridge, in addition to the science behind the formation of the beach ridge.

\section{SIGNIFICANCE}

In Alberta, eolian (wind blown) beach ridges are a relatively rare feature with a total of 22 occurrences known in the province. Of these 22 ridges, nine occur within protected areas, while the remainder is found in non-protected areas. Devonshire Beach represents one of the only beach ridges with road access. The Special Places Provincial Co-ordinating Committee in 1998 described the Lesser Slave Lake Provincial Park as having the best eolian beach ridges in Alberta (Alberta Environment 1998).

The beach and beach ridge are also significant to the local First Nations. The Sawridge Band derived their name from the saw tooth pattern that forms on the beach ridges and the area was used extensively in historical daily life (i.e. fishing, berry collection, recreation).

\section{DISTURBANCES}

During the field surveys performed in May 2004, a total of 23 both human and natural disturbances were noted along the lakeside of the active beach ridge at Devonshire Beach.

\section{Human Disturbances}

- Gravel road that runs along length of the beach ridge.

- Prevents the beach ridge from prograding upward as the migrating sand has to be removed from the road to keep it passable.

- Series of pull-offs that occur beside the beach ridge road without controlled access to the beach

- Resulting in erosion on uncontrolled trails downslope of the pull off

- Incorporation of road gravel into the beach ridge sands

- Construction of the weir and 8 channel cut-offs, stabilizing Lesser Slave Lake water levels 

- Potential changes to wave action, and the quantity and movement of sand available for beach ridge formation and maintenance

- Beach Grooming

- May allow for vegetation to encroach on the sandy beach

- Approximately 350 metres length of the beach are groomed to improve recreation use, particularly with respect to the annual sand castle competition

- Grooming controls vegetation encroachment along the beach. The effects of this activity on beach ridge development are not known, but the grooming does allow for sand to migrate to the fore dunes and beach ridge

\section{Natural Disturbances}

\section{Natural erosion, as slumps and rills}

- Often associated with steeper portions of the beach ridge, but the disturbances were isolated and limited in extent.

- Animal trails are visible along the beach ridge, but erosion associated with this disturbance does not appear to be severe.

With any management plan, cooperation and understanding is essential from stakeholders and users of the area. Questionnaire results provided suggestions of field trips, seminars and various media extension material to inform and educate people on the management plan that is to be developed.

\section{RECOMMENDATIONS}

Four options were provided in regards to recommendations on conservation and management of the beach ridge. Any decision on the best way to manage Devonshire beach will be dependent on management goals and associated funding.

1. No Mediation. This option has no direct intervention and allows for nature to take its natural course in the area.

2. Low Mediation. Maintains the status quo of the area. Current management in terms of the area that is groomed on the beach, the road, pull-offs, parking lots, trails, boardwalks, fences and picnic areas is maintained.

3. Moderate Mediation. This option allows for some of the disturbances to be mitigated, particularly in regards to the current erosion on the beach ridge. The ungroomed portions of the beach would be scoured to control encroaching vegetation and extend the groomed beach for recreational purposes.

4. High Mediation. This option would allow for extensive rehabilitation of the beach ridge. This plan would be costly, but the main gravel road and houses along Devonshire Beach would be decommissioned and potentially a moveable weir installed to allow for greater lake level fluctuations.

A number of studies have been recommended for the area, one of which includes a biophysical inventory of the beach ridges east of Devonshire Beach on the east side of Highway 88 as possible areas to preserve. Another recommended study is to investigate current and historical impacts on sand movement and vegetation encroachment since the installation of the weir and channel straightening in 1983. Monitoring for external disturbances within the watershed and assessing the development of the new beach ridge that may be forming may also prove useful future endeavors. 



\section{Table of Contents}

Executive Summary.

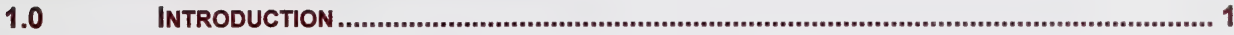

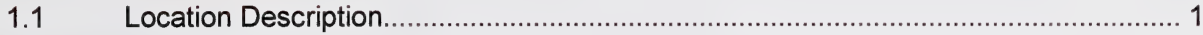

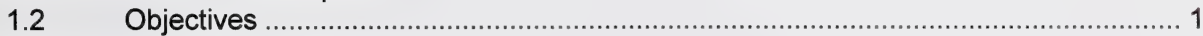

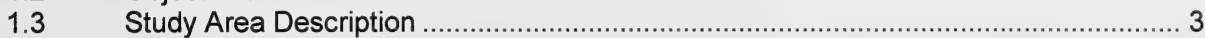

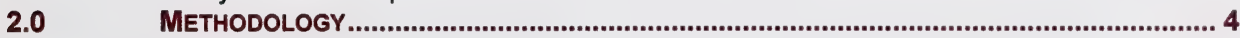

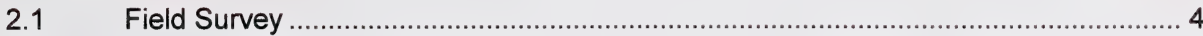

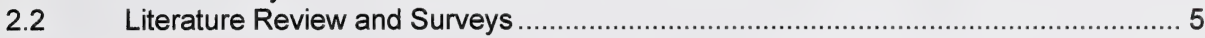

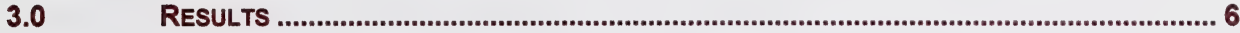

3.1 Formation of the Beach Ridge Literature Review ............................................... 6

3.1.1 Historical Background on Beach Ridge Formation ............................................ 6

3.1.2 Current Processes of Beach Ridge Formation .................................................. 6

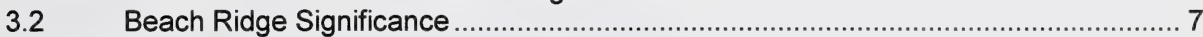

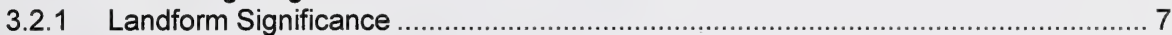

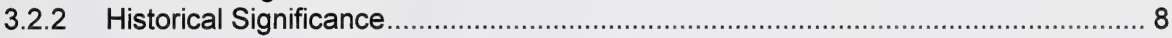

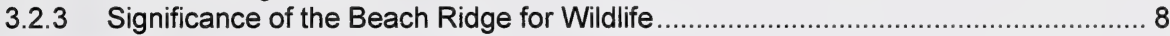

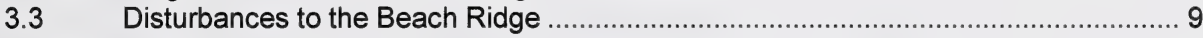

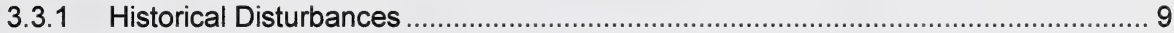

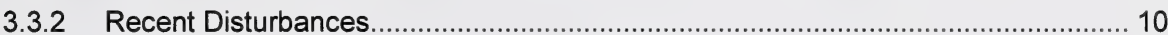

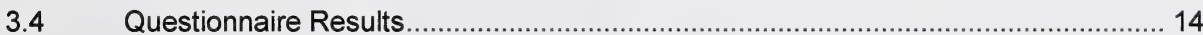

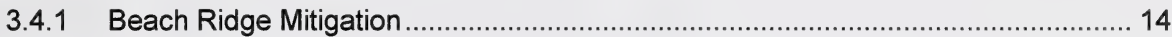

3.4.2 Public Involvement..................................................................................... 15

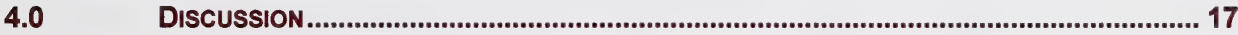

4.1 Research Protocol Critique and Study Limitations ............................................ 17

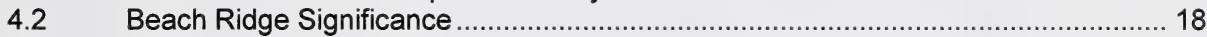

$4.3 \quad$ Beach Ridge Disturbance ............................................................................ 18

4.4 The Role of Vegetation on the Beach and Ridge ............................................... 19

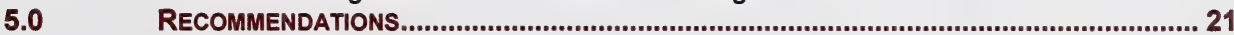

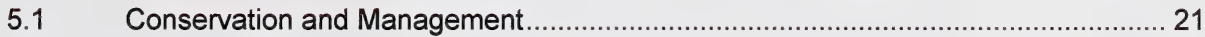

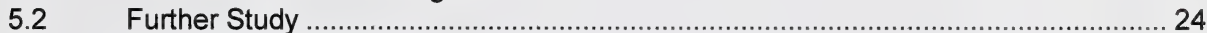

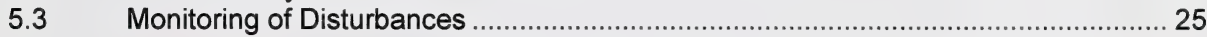

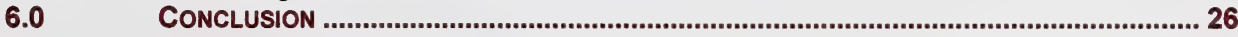

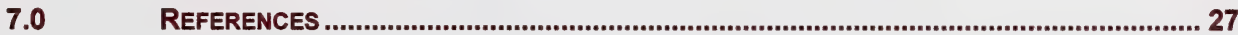





\section{List of Tables}

Table 1. Individuals contacted for surveys.

\section{List of Figures}

Figure 1. Beach ridge significance and disturbance study area along Devonshire Beach........... 2

Figure 2. Devonshire Beach ridge..................................................................................... 3

Figure 3. Three main habitat types identified at Devonshire Beach...................................... 4

Figure 4. Photo of ungroomed beach providing butterfly habitat. ......................................... 9

Figure 5. GPS locations of disturbance along Devonshire Beach are red dots on the map........ 11

Figure 6. An example of erosion downslope from the pull-offs on the ridgeline. ....................... 12

Figure 7. Road located along Devonshire Beach ridgeline ................................................... 13

Figure 8. Erosion associated with trails from pull-offs........................................................ 13

Figure 9. Erosion associated with trails from pull-offs. ......................................................... 13

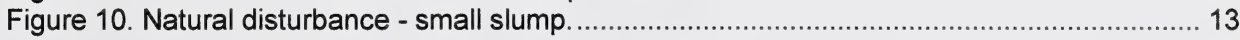

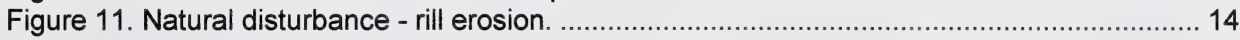

Figure 12. Use of fencing to capture sand and control erosion......................................... 22

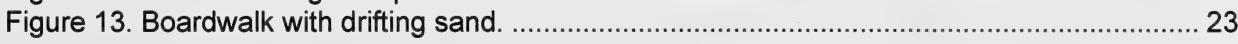

\section{Appendix A Significance Evaluation}





\subsection{Introduction}

\subsection{Location Description}

Alberta Community Development, Parks and Protected Areas Division, is preparing a management plan for Devonshire Beach along with the Town of Slave Lake, the Municipal District of Lesser Slave River \#124, and other stakeholders. Alberta Community Development, Parks and Protected Areas, retained Geowest Environmental Consultants to conduct a biophysical study that was divided into two parts:

- An assessment of the beach ridge to determine its level of significance and disturbance, and

- A vegetation inventory and rare plant survey.

This portion of the study dealt specifically with the beach ridge as a landform. The study was aimed to establish the significance of the beach ridge using existing literature and questionnaires. The second portion of the study was to assess the current disturbances that are present along the lakeside of the beach ridge. This information in turn was to provide insight for recommendations on the management of Devonshire Beach.

The management of Devonshire Beach, which is located in Lesser Slave Lake Provincial Park, presents the challenge of trying to maintain the natural landscape while allowing for multiple-uses such as recreation and tourism. The proposed management plan will attempt to balance human activities with the natural processes of the beach ridge. This challenge requires a thorough understanding of the current impacts on the ecology of the beach ridge, and what is required to sustain the naturalness of the landscape.

\subsection{Objectives}

The purpose of the Beach Ridge study was to:

To establish the significance of the beach ridge as a landform feature (in Alberta),

$>$ To document the disturbances from natural causes and human use, and

$>$ To provide recommendations for management and mitigation of disturbances.

In order to meet the purposes of the report the following objectives were developed:

$>$ To complete a literature review and interview academics concerning the science behind beach ridge formation;

$>$ To establish the significance of the beach ridge from a provincial and regional perspective based on available literature;

$>$ To conduct a survey of individuals from the local community and from relevant stakeholder groups;

$>$ To document disturbances to the beach ridge and to make recommendations for mitigation and management of human activities that may negatively affect it; and

$>$ To provide a summary report.

The results of this study will provide information for the preparation of the Devonshire Beach management plan. 



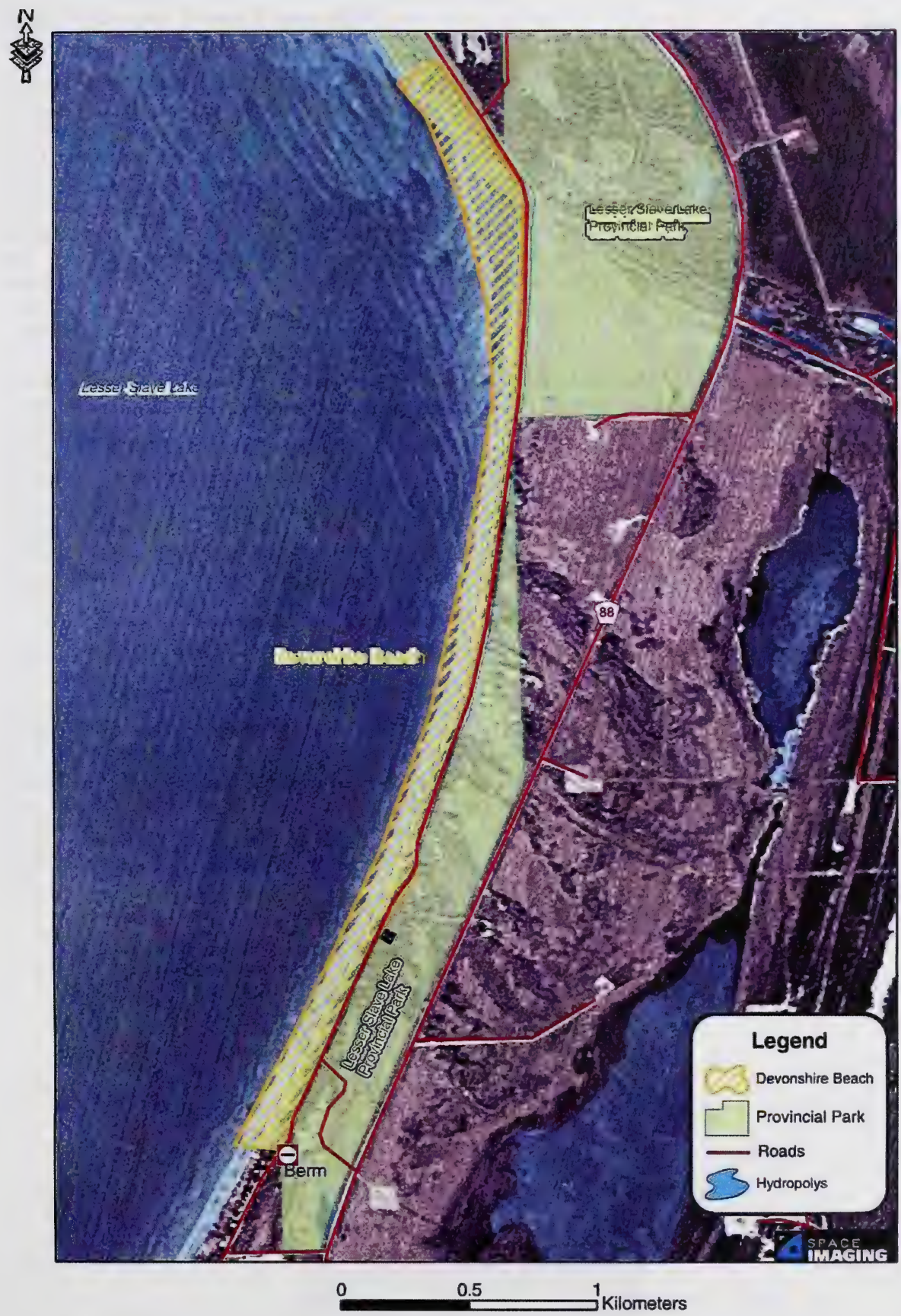

Figure 1. Beach ridge significance and disturbance study area along Devonshire Beach. 



\subsection{Study Area Description}

Lesser Slave Lake, located approximately $250 \mathrm{~km}$ north of Edmonton, is the second largest lake in Alberta, second only to the Lake Claire - Lake Athabasca complex that is located in the northeast corner of the Province (Bentz and Saxena 1993, Brandford and Hanson 1990). The lake has a surface area of $1,150 \mathrm{sq} \mathrm{km}$ and maximum depths of $21 \mathrm{~m}$ (Bradley 1980). The large size of the lake allows strong westerly winds to sweep over it, which causes a set-up at the east end of the lake and a decline in water levels at the west end. This oscillation can result in waves several feet high at the southeast end of the lake. Fine sand beaches at the east end of the lake are maintained by a combination of high water levels and high energy storms, drawing large amounts of sand from the headlands and depositing it in long shore drifts on the beaches. Most of the thicker sand deposits are found along Devonshire Beach, which is located in Lesser Slave Lake Provincial Park, as shown in Figure 1.

Devonshire Beach is located in Lesser Slave Lake Provincial Park on the southeast shore of Lesser Slave Lake. Sandy beaches and an eolian (windblown deposit of sand) beach ridge that parallels the shoreline for several kilometers characterize the area. The beach ridge has been created and is maintained, by the process of sand being carried by shore drift toward the southeast corner of the lake and deposited on shore by wave action. Above the beach, the beach ridge parallels the shoreline for approximately 4.9 kilometres. Significant beach ridges are commonly associated with coastal areas, but this ridge is land-locked (Smith 1987), making it a unique landform in the province. At the present time, the beach ridge is stabilized by encroaching vegetation, except for several blowout areas, which occur along the ridge. Vegetation grows in swales along the beach.

Devonshire Beach, with its clean white sand attracts many tourists, and is a popular recreation site for local people. Devonshire beach represents one of the best recreational beaches in the province (Bradley 1980) and hosts an annual sandcastle competition. A former stretch of Highway 88 located on top of the beach ridge is now used as access to the beach for recreational use. A number of pull off areas are located along the ridge and a large paved parking lot is located on the backside of the current beach ridge. The area has undergone some reclamation in the 1970's to control the movement of sand caused by human disturbance to the area (Lesko 1974). The reclamation was deemed successful and today much of the beach ridge is vegetated and stabilized, with the exception of a few blowouts along portions of the beach ridge as shown in Figure 2.

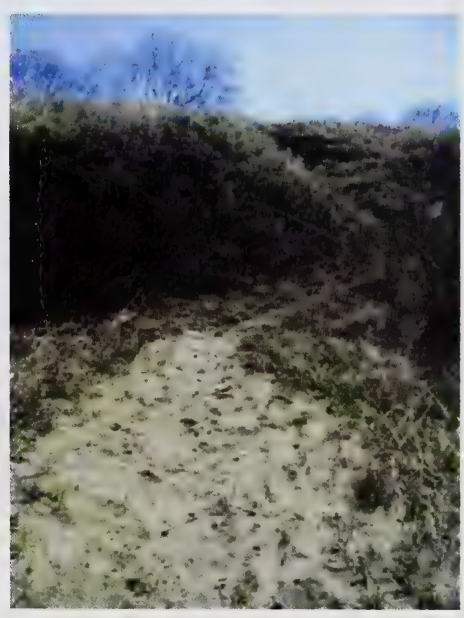

Figure 2. Devonshire Beach ridge. 



\subsection{Methodology}

\subsection{Field Survey}

To facilitate the Devonshire Beach survey, the study area was divided into three main habitat types based on landform and associated vegetation, (1) Beach Habitat Type, (2) Fore-dune Habitat Type and (3) Mixedwood Beach Ridge Habitat Type.

The Beach habitat is readily influenced by lake processes, such as waves and moisture availability with most of the area being open sand. Willows, rushes and grasses are dominant in some areas. This community has little to no soil development due to the active lake and wind processes taking place.

The Fore-dune habitat type is composed of early seral vegetation, primarily aspen, balsam and willow. Erosional and depositional forces influence the second community and a large proportion of sand is not stabilized. This community has immature soils that are largely devoid of organic matter and susceptible to disturbance.

The Mixedwood habitat type was a late seral-stage community with a mixedwood canopy cover and a well-developed understory of forbs and grasses. This community occurred on the beach ridge and was relatively more stable. Soils were Eutric Brunisols with a thin organic layer (Chabaylo and Knight 1997). Much of the sand was stabilized and vegetated, however, there were a few areas of destabilized sand and blowouts with impeded soil development. Figure 3 depicts these community types along the beach ridge.

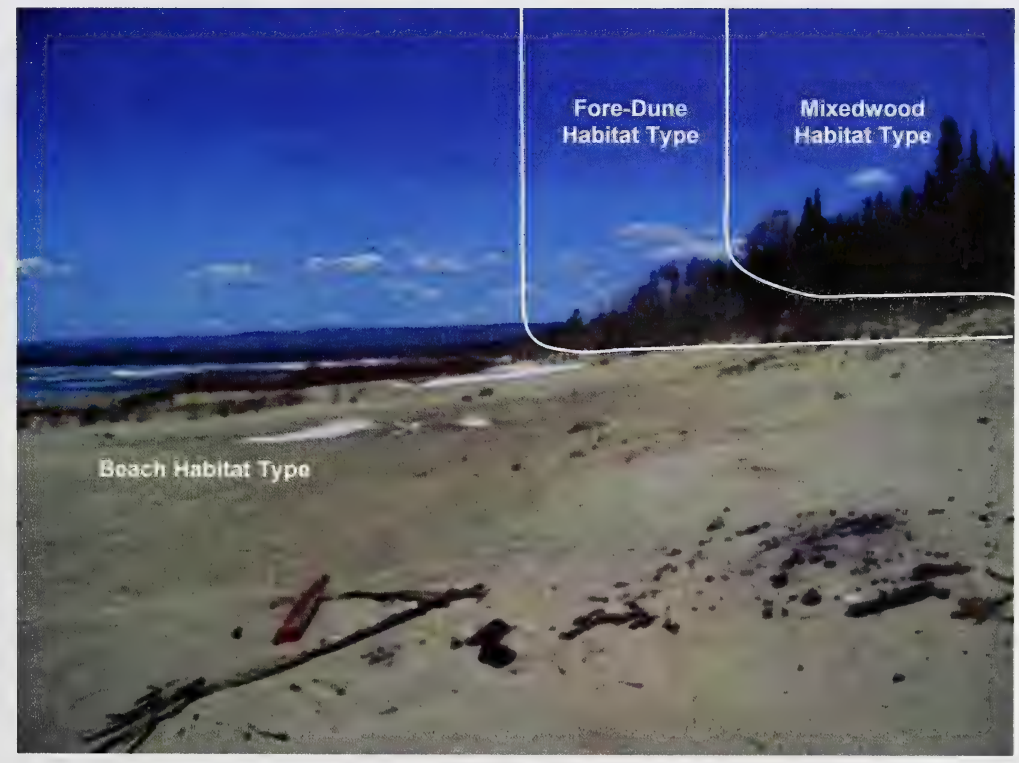

Figure 3. Three main habitat types identified at Devonshire Beach.

There were sections of beach on the northern portion of the study area had a large number of cobbles within the sand matrix. Here vegetation cover was higher than similar un-cobbled sites 

along the shoreline. Some of these sections of beach had shallow depressions that supported willow and sedge swamps.

To assess the level of disturbance to the community, the entire length of the beach ridge was first driven, and then examined more closely by walking from above and below the ridge. GPS coordinates of all significant disturbances were recorded and notes describing the type of disturbance and the current condition of the beach ridge were also made. A digital image of each significant disturbance was also taken. Observations of past mitigative measures to control erosion were made, as were observations of wildlife within the study area. Wildlife observations included evidence of past and current presence, along with direct sightings of significant wildlife species.

\subsection{Literature Review and Surveys}

A series of relevant articles, reports and published work were reviewed to assess beach ridge significance. The literature review assisted in understanding the processes involved in beach ridge development along Devonshire Beach. The literature search was also used to determine historical and present uses of the beach.

Upon completion of the literature review, a few information gaps were discovered. The crucial gaps concerned processes that lead to the development of the Devonshire Beach ridge, the current state of the Devonshire Beach ridge and its historical significance. First hand knowledge and recommendations were deemed valuable for the future management plan, so local and knowledgeable individuals were contacted. (Table 1) Approximately half the contacts responded that were listed in Table 1. The information obtained from these surveys was integrated into this report.

Table 1. Individuals contacted for surveys.

\begin{tabular}{ll}
\hline Name & Area of relevant knowledge \\
\hline Dr. Derald Smith & Specializes in coastal landforms \\
Nolan A. Turner & Reclamation at Devonshire \\
Grant Kihn & Conservation Officer \\
Wayne Nordstrom & Zoologist, Community Development \\
Jean Anne Fraser & Former planner at Slave Lake \\
Aaron Lehman & Local from Slave Lake \\
Raghbir Mangat & Horticulturalist worked at Devonshire \\
Eugine Lin & Horticulturalist worked at Devonshire \\
Roland Eben-Ebenau & Stakeholder along Devonshire \\
Roland Twinn & Chief of the Sawridge First Nations \\
Dr. Harry Jol & Specializes in coastal processes \\
Frank Fraser & Lesser Slave Lake Bird Observatory \\
Bob Deacon & Lesser Slave Lake Bird Observatory \\
\hline
\end{tabular}





\subsection{Results}

The results section presents the findings of the three components of the beach ridge study. The first component provides information in regards to the literature written on the existing beach ridge. The literature provides the background of how the beach ridge is formed and the current processes that currently affect it. The second portion of the results will detail the disturbances the beach ridge has undergone and what disturbances currently exist on the ridge. The current disturbances will be the findings from the field portion of the biophysical study of the beach ridge. The final section will provide the findings from the survey questionnaires that were completed over the past 4 months. Those findings outline the how the beach ridge is viewed as a landform and some information on allowing the public to participate in preserving the beach ridge.

\subsection{Formation of the Beach Ridge Literature Review}

\subsubsection{Historical Background on Beach Ridge Formation}

Beach ridge development in this area began over 10,000 years before present times, when Glacial Lake Peace/Edmonton covered much of the area of Lesser Slave Lake (Clack 1998). The eastern extent of the shoreline was approximately 1 to 2 kilometers inland from the lakes existing shoreline. As glacial lake levels dropped (over the next 2,000 years), the first phase of the beach ridges (at the time of the development were termed the barrier sequence) was initiated as recurved spits. A recurved spit, also known as a "hook" is defined as "the end of a spit of land that is turned toward shore" (Parker 1997).

Approximately 6,665 years before present, four barriers which extended beyond the boundaries of Devonshire Beach formed as the initial recurved spit pro-graded westward (Clack 1998). The sands have subsequently been reworked by water and wind into a series of long, linear parallel ridges exhibiting a relief of 2 to $4 \mathrm{~m}$ (Bradley 1980). A portion of this sequence of ridges is still visible east of Highway 88 . East of these ridges, the old bay has become in-filled with large wetland complexes (Bradley 1980).

During the past 6,000 years, the lake has been subjected to various climatic changes resulting in fluctuating lake levels (Clack 1998). The current ridge located along Devonshire Beach is the largest beach ridge in the sequence of ridges to date (Jol, pers. comm. 2004). The current beach ridge is the largest in the sequence, largely due to the stabilization of the area after isostatic rebound (the natural uplift of the land since the last ice age). Due to the unstable nature of sand, this formation, which has taken thousands of years to develop, could easily be lost to disturbance, particularly man-made disturbance.

\subsubsection{Current Processes of Beach Ridge Formation}

The current Devonshire Beach ridge formation derives its materials from lake bottom deposits at the lake's southeastern edge. Strong westerly winds cause a set-up of a few feet at the east end of the lake. High water levels combined with high-energy storms are responsible for drawing large amounts of sand from headlands into the long-shore drift, to be subsequently deposited on the beaches (Lombard North Planning Ltd, 1972). This natural process serves to replenish the sand on the beaches, which are continually being eroded (Bradley, 1980).

Upshore from the beach, sand movement is also influenced by water and wind. Sand accumulates behind small obstacles such as driftwood, stones, debris or vegetation. Vegetation 

from seed and root suckers within adjacent established stands invaded other areas along the beach creating conditions favorable for further sand accumulation. Because this vegetation is growing in marginal conditions, it is vulnerable to natural and human disturbances. Vegetation growing in these areas is typically tolerant of high salinity, extreme glare, deficiencies in soil organic matter, and oscillating soil moisture (BKA and Turner, 1996).

\subsection{Beach Ridge Significance}

\subsubsection{Landform Significance}

The beach ridge located along Lesser Slave Lake is rare for Alberta. The main reason the type of beach ridge found along Devonshire beach is so rare is that large lakes with large amounts of sand are required for its formation (Smith pers. comm. 2004). Three large lakes within Alberta that could form beach ridges based on their size include Lake Athabasca, Lake Claire and Lesser Slave Lake. While Lake Athabasca does have well formed beach ridges, the majority of them are located in Saskatchewan. Lake Claire has limited beach ridge formation because it has a clay bottom and insufficient sandy material to build ridges (Smith pers. comm. 2004). Regionally and provincially, the beach ridge found on Devonshire Beach represents a classic example of a beach ridge, and is the only relatively intact ridge that has road access (Kinn pers. comm. 2004, Jol, pers. comm. 2004).

The Devonshire Beach ridge is distinct, due to its formation process. Beach ridges are usually eolian-deposited features associated with coastal processes that include tidal activity. However, the beach ridges located along Lesser Slave Lake are unique in that they are eolian features associated with lake origins and are located in the centre of land-locked Alberta (Smith 1987). Although these features are generally associated with coastal processes, similar beach ridges are found elsewhere in Canada, including those found along the east coast of Lake Huron at Ipperwash Provincial Park.

In Alberta, eolian (wind blown) beach ridges are a relatively rare feature. A total of 22 occurrences have been recorded for the province (AE 1998). Of these 22 ridges, nine occur within protected areas, while the remainder is found in non-protected areas (AE 1998). Devonshire Beach represents one of the only beach ridges with road access (Kihn, pers. comm. 2004) and its formation is a classic example of a beach ridge. Beach ridges are extremely sensitive to man-made disturbance (Saxena and Bentz 1993) but are often utilized for road building and infrastructure sites because of the high amount of sandy material. The Special Places Provincial Co-ordinating Committee in 1998 described the Lesser Slave Lake Provincial Park as having the best eolian beach ridges in Alberta (AE 1998).

Based on a series of rankings given by Alberta Environment, the beach ridges near and at Devonshire have outstanding provincial significance in the category of Environmental Significance. The evaluation of Environmental Significance is based on the need for conservation, noteworthiness or outstanding nature of a special feature and the special elements contained within it. The 1998 evaluation of Lesser Slave Lake Provincial Park is summarized in Appendix $A$ and contains a description of the evaluation criteria.

Unfortunately, some beach ridges outside of the Lesser Slave Provincial Park have been disturbed by wellsite and cutline construction, emphasizing the need for the proper management of intact eolian beach ridges. This landform needs a form of conservation as it is threatened in the province by human activities due to the well-sorted material it contains for road building and other resource related activities 



\subsubsection{Historical Significance}

The name of Lesser Slave Lake owes its origin to the first inhabitants of the area, who were called Slaves by the Cree (Bradley 1980). David Thompson is one of the early explorers to arrive on the shores of Lesser Slave Lake in 1799. From that point in time until 1820 the area was used primarily for the fur trade. In 1922, the Canadian Pacific Railway (CPR) expressed an interest in developing the area for recreation, particularly for the sandy east shore of the lake. In 1925 the provincial government made provisions to leave the shore as public lands and in 1966 it formally became known as Lesser Slave Lake Provincial Park (Bradley 1980, Alberta Provincial Parks, n.d.).

From a historical perspective, the beach ridge is significant for several reasons. This ridge is one of a sequence of ridges in the area. These ridges have sand that drifts in a saw tooth pattern. It is from these landforms that the local First Nations people derived their name as the Sawridge Indian Band (Twinn pers. Comm. 2004). The ridge has historically been significant to the local First Nations culture. Berries were picked in the region. The area also contained an important trail that went to the north shore of the lake where several communities existed. It allowed families to visit one another and provided a gathering place for the indigenous people of the area. The ridge also allowed access to areas along the north shore of the lake containing sweet grass and plants used as medicines by First Nations people (Twinn pers. Comm. 2004).

First Nations fisherman used the beach to dry and clean their nets, and their children played and swam in the area. It was used as a recreation area for the first inhabitants of this area prior to the park being established.

\subsubsection{Significance of the Beach Ridge for Wildife}

The study area represents a unique habitat for animals as a transitional zone where land and water meet. The range of life forms is extensive, from algae and microfauna, to migratory shorebirds. During the field visit it was observed that driftwood piles and other beach debris contained a variety of beetles, ants and spiders, providing food for shorebirds. The beach ridge has an associated swale where wetlands are found (east of the road, west of the highway). These wetlands serve to provide habitat for many types of waterfowl.

During our field visit in May 2004, a pair of bald eagles was observed roosting in trees along the beach ridge. The lake provides fish as a food source for the eagles.

The fore-dune area contained shorebird nests, likely including a killdeer nest. Although we were unable to locate the killdeer nest, the bird did display the injured wing technique to draw us away from the area we were surveying, leading us to believe there was a nest nearby. Gull eggs were located near a willow stand, nestled in the sand.

During the spring visit, evidence of mammals was noted in the area of the beach ridge. Deer scat and recent hoof prints were observed. Bear scat was also found during the survey, which was likely from the previous season, as it contained a large number of berries. The beach ridge vegetation is suitable for black bears as the large number of Saskatoon and chokecherry shrubs would provide a source of food.

During the vegetation survey in June 2004 a large number of flowers were in bloom in the ungroomed sections of the beach. These flowers provided habitat for a variety of butterflies (Figure 4). 



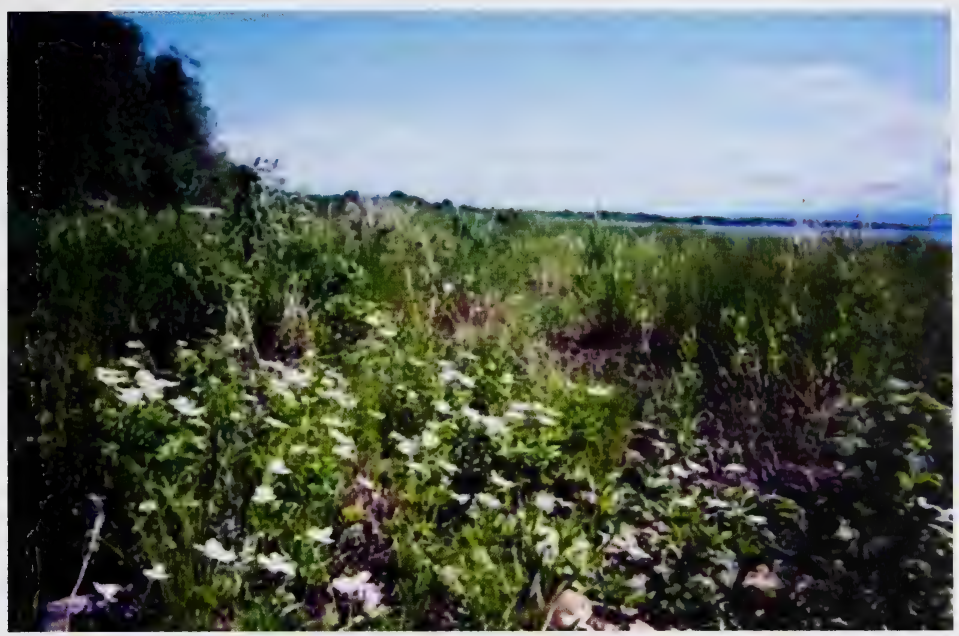

Figure 4. Photo of ungroomed beach providing butterfly habitat.

Faunal species that have been noted in the literature that make use of the beach and beach ridge area included killdeer, spotted sandpiper, herring gull, ring-billed gull and Franklin's gull. Migrant shorebirds observed in the early spring and late summer included black-bellied plover, semipalmated plover, pectoral sandpiper, long-billed dowitcher and least sandpiper (Bradley 1980).

In the wooded areas and wetland depressions associated with the beach ridge, birds such as the red-eyed vireo, yellow-rumped warbler, chipping sparrow, white-throated sparrow, American robin and Leconte's sparrow have been recorded. Some of the mammals found in the treed areas of the beach ridge included red squirrels and least chipmunks (Bradley 1980). A large number of animals use the large wetland complex between the lakeshore beach ridge and the parallel series of ridges to the east, most of which presently lie outside the park. The area has been rated as highly productive for waterfowl and aquatic furbearers (Doberstein 1978, Bradley 1980).

\subsection{Disturbances to the Beach Ridge}

\subsubsection{Historical Disturbances}

The beach ridge and associated dune environment is particularly sensitive to erosion and disturbance. Recreational overuse in specific areas, historic sand excavation for highway construction on portions of the dune system, and human and animal trampling has caused regression of vegetation. In some instances, the sparse growth has led to a reactivation of these dune areas (Lombard North Planning Ltd. 1972, BKA and Turner 1996).

In 1973 a reclamation plan was initiated to control sand blowouts and restore the vegetation that was lost to recreational overuse and sand excavation (Lesko 1974). The plan involved plantings of vegetation with fertilization. Reclamation to a more natural state along the beach ridge was complicated by the paucity of nutrients in the substrate, the inherent instability of sand, and the unavailability of native plant horticultural seed mixes suitable for sandy environments. As a result many introduced species were used, which have the ability to out compete natural vegetation. Management guidelines now encourage the protection of these areas from further surface disturbance and promote the reclamation of disturbed areas to as close as possible an approximation of their natural state (Bradley and Loomis 1978, BKA and Turner 1996). 

The water levels in Lesser Slave Lake have varied over a range of 3.5 metres (11.5 feet) since levels have been monitored in 1915 (AEP 1993). Flooding occurred along agricultural portions of the south and west sides of the lake where the backshore is low and sloping, when water levels were high. After other means of controlling water levels were evaluated, the Lesser Slave Lake Regulation Environmental Impact Assessment study was initiated. Eight channel cutoffs were constructed in 1981 and 1982 to improve the flow capacity of the Lesser Slave River (Mitchell and Prepas 1990). Consequently, maximum lake levels were reduced as these modifications increased lake outflow. A 30-metre weir was also constructed on the lake outlet in 1983, which was designed to maintain a minimum lake level of 575.5 metres (Mitchell and Prepas 1990).

\subsubsection{Recent Disturbances}

\section{Human Disturbances}

During the field surveys performed in May 2004, a total of 23 natural and man-made disturbances exist along the beach ridge, as shown in Figure 5, including:

1. The road that runs along the ridgeline

2. Pull-offs

3. Beach grooming

4. External disturbances

Most of the disturbances were a result of the construction of a series of pull-offs that occur beside the beach ridge road. Most of these pull-offs did not have controlled access to the beach resulting in erosion on uncontrolled trails downslope of the parking lot. Figure 6 shows an example of this type of disturbance.

\section{Gravel Road}

The primary disturbance along the beach ridge is the unpaved road that runs the length of the ridge (approximately 4.9 kilometres), as shown in Figure 7 . This road has been in place as a travel route for many years. Historically this road used to be part of Highway 88 , which has now been re-routed. As suggested in Section 4.1.2, the beach ridge was also used historically by First Nations people and by early pioneers. Sand drifts along the top of the road and is removed each time the road is graded

\section{Pull-offs}

The second series of disturbances to the beach ridge are the small pull-offs that occur on the beach side of the road. These pull-offs show signs of erosion resulting primarily from trails used to link the parking lot on the top of the ridge, to the beach. Some of the pull-offs have signs discouraging the damage of vegetation caused by trampling, however informal trails do exist and erosion is evident (Figure 8 and 9). Some pull-offs also had some gravel mixed into the top layer of the sand. It was assumed the gravel was introduced during road construction and maintenance activities.

\section{Beach Grooming}

Approximately 350 metres of Devonshire Beach are groomed each year. Fifty metres are groomed near the handicap platform and the remaining 300 metres is at the south end of the beach. The grooming is designed to keep the sand beach clear of vegetation and debris. This portion of the beach represents where a considerable amount of recreation is concentrated along Devonshire Beach.

\section{Water Level Controls}

The construction of the weir and 8 channel cut-offs have affected Lesser Slave Lake water levels: 

- Higher water levels (i.e. flooding) does not occur as frequently or as severely,

- Low water levels are not as extreme

- The regulated average water level of 576.3 metres is lower ( 0.3 metres or one foot) than under natural conditions

- The overall variation in water levels is reduced from 3.5 metres to 2.7 metres (AEP 1993)

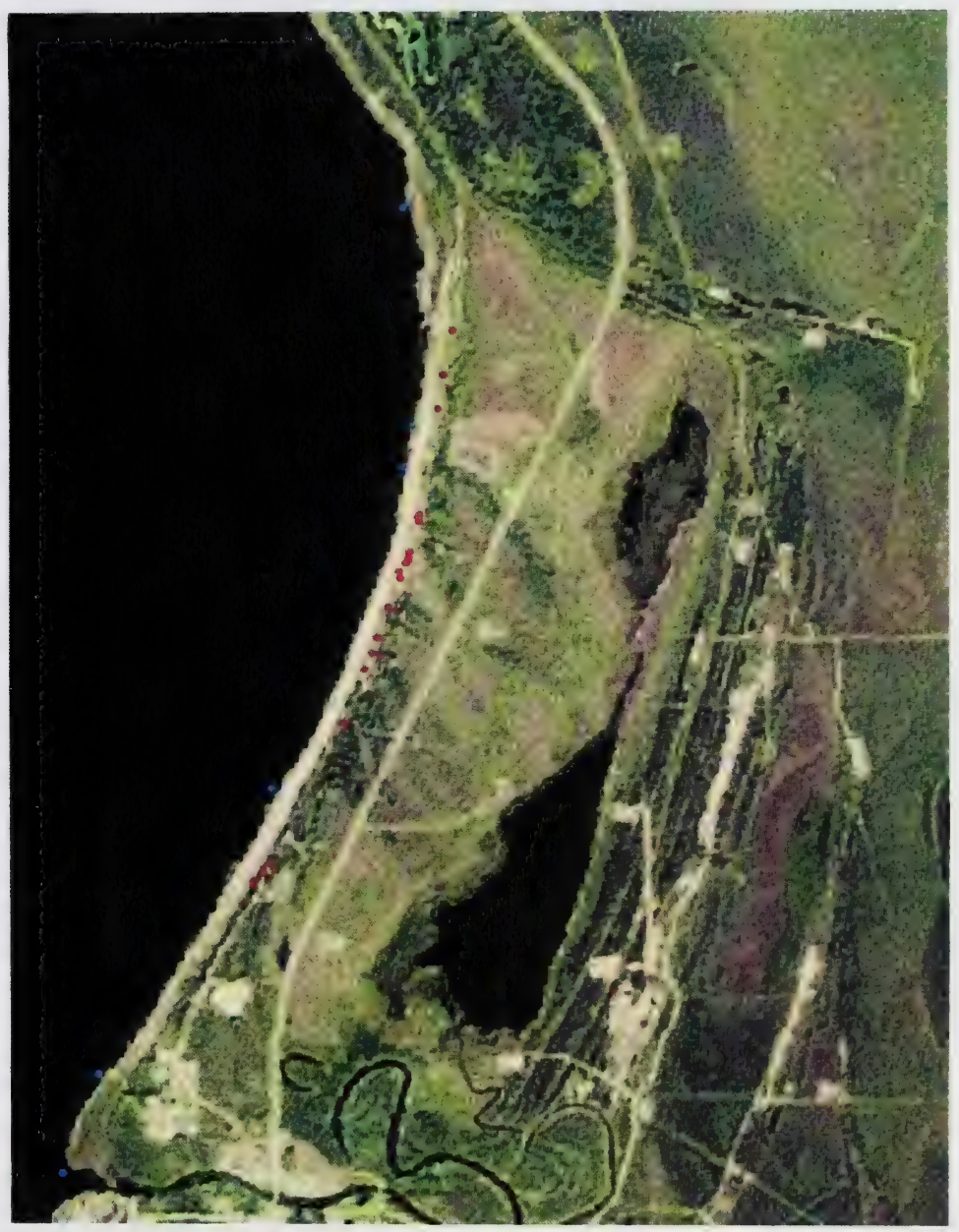

Figure 5. GPS locations of disturbance along Devonshire Beach are red dots on the map. 



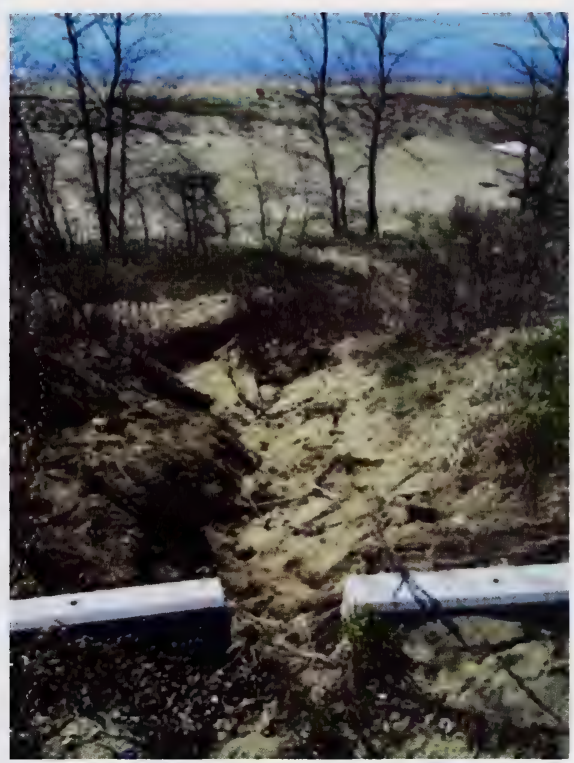

Figure 6. An example of erosion downslope from the pull-offs on the ridgeline.

\section{Natural Disturbances}

Natural disturbances also occur on the beach ridge. Areas of erosion were noted as slumps and rills where man-made influences were not readily apparent (Figure 10 and 11). These areas were often associated with steeper portions of the beach ridge, but the disturbances were isolated and limited in extent. 



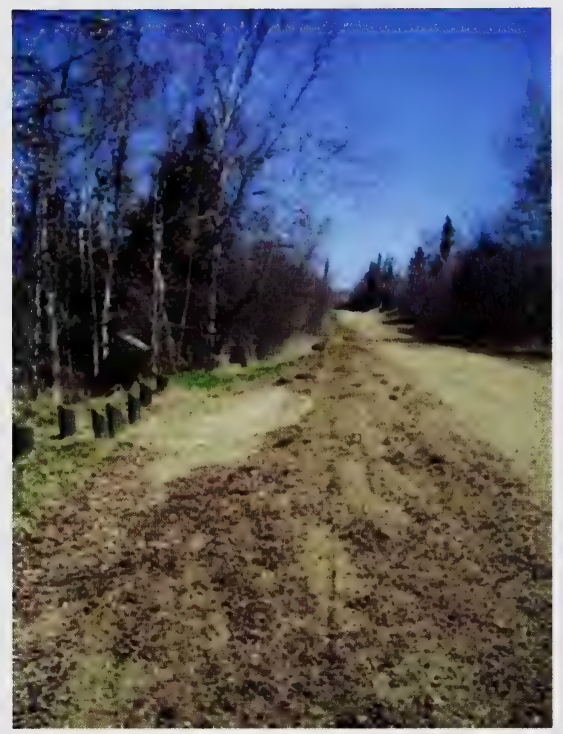

Figure 7. Road located along Devonshire Beach ridgeline.

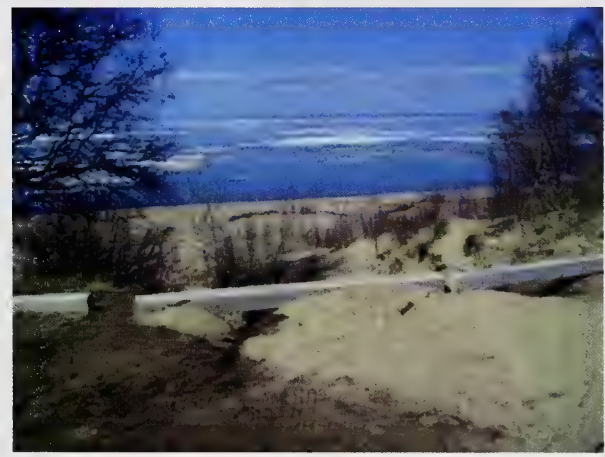

Figure 8. Erosion associated with trails from pull-offs.

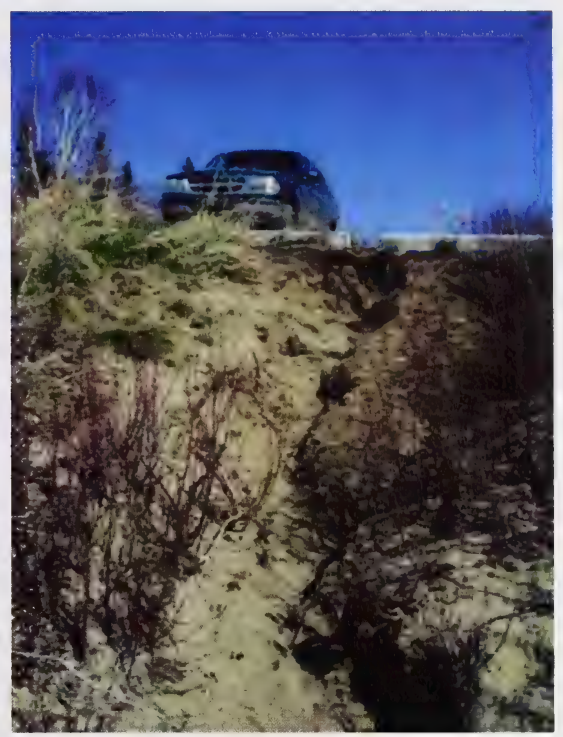

Figure 9. Erosion associated with trails from pull-offs.

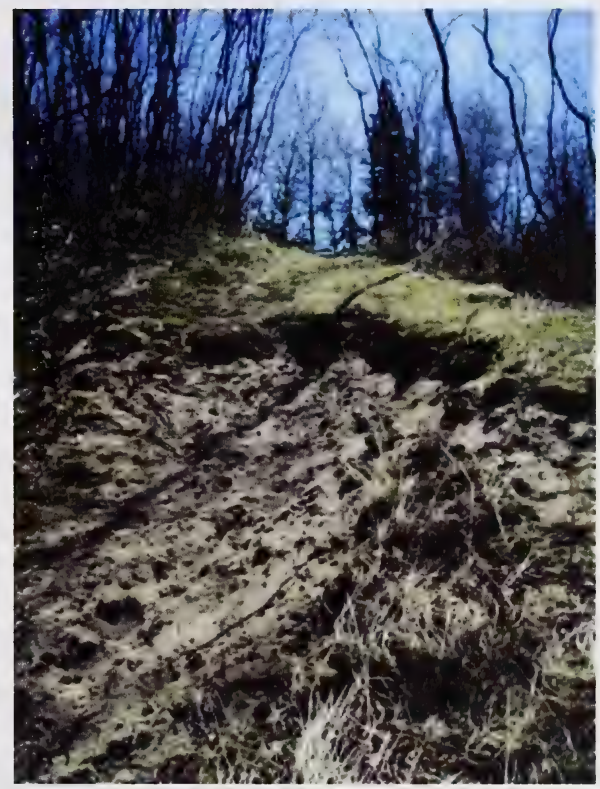

Figure 10. Natural disturbance - small slump. 



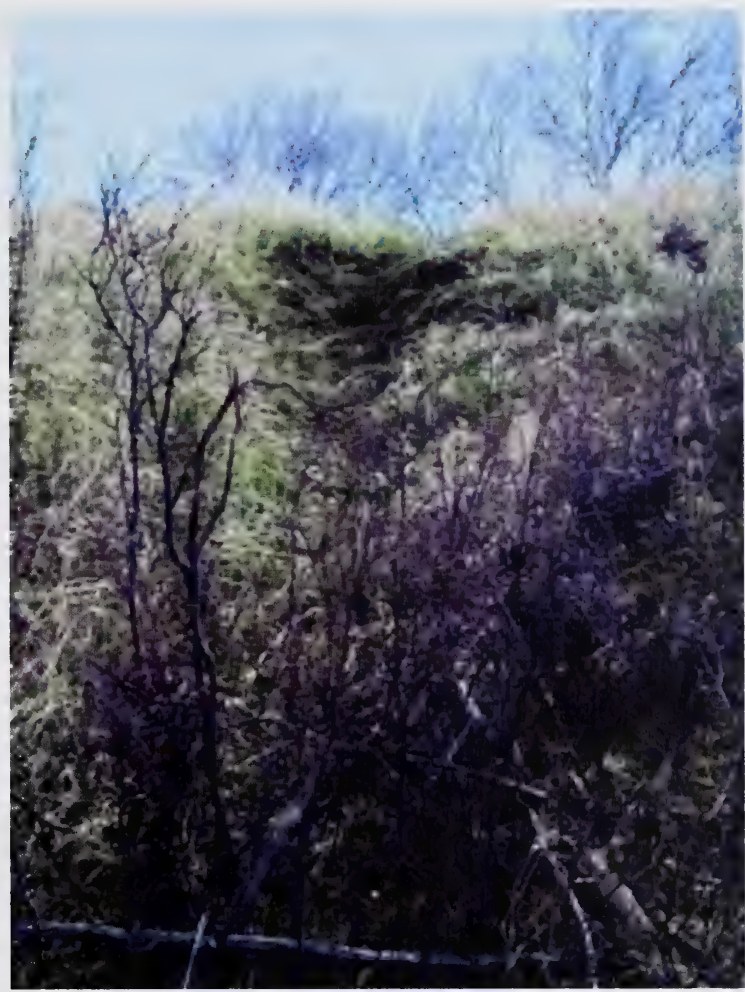

Figure 11. Natural disturbance - rill erosion.

\subsection{Questionnaire Results}

\subsubsection{Beach Ridge Mitigation}

Currently, Devonshire Beach has an established road with parking areas and associated trails. From the Questionnaire information it becomes readily apparent that public access in some form needs to be maintained. J. Fraser (2004) suggested that the government should allow for lowscale development of the area and promote a trail system that provides public education and conservation. Along with low impact activities and the development of light passive recreation, some parts of the area should be screened off or detoured to prevent potential damage to sensitive or vulnerable portions of the beach and beach ridge (J. Fraser, pers. comm. 2004). Expansion of the trail system on the backside of Devonshire was also recommended. Part of the attractiveness of the beach ridge and beach is that it is readily accessible allowing for the observation and use of the area. Other beach ridges such as the Athabasca Sand Dunes are remote and inaccessible by car (F. Fraser pers. comm. 2004).

Controlled access was also recommended in many of the Questionnaires. Snow fences have in part controlled foot traffic and impeded the use of All-terrain vehicles (ATVs). More extensive use of stairs and boardwalks from the top of the beach ridge to the beach would help control erosion. That has proven to be effective on the south end of the beach ridge and was generally found to be an acceptable alterative to footpaths that are currently subject to visible levels of erosion. 

Further suggestions for controlled access were in the form of observation and staging areas that would limit access. These areas would provide information to potential beach users as to why preservation of the area is important. One currently exists on the beach, and this has proven to be effective. People need to have a visual link to what is being conserved and protected, and to have opportunities to view dunes and the many plant species occurring in the park. The beach area also needs interpretive media to provide information that helps to express its uniqueness and importance (J. Fraser pers. comm. 2004).

Some of the local people interviewed felt that the beach that runs parallel to the beach ridge should have the vegetation removed. They felt that the weir and channel straightening prevented high lake levels, which in turn influenced the scouring ability of the lake waters. They felt that this particular disturbance was the reason for vegetation encroachment along the beach, which has created a perceived need to clear the beach (Eben-Ebenau, pers. comm. 2004, Twinn pers. comm. 2004). If the beach is to be cleared, impacts on the beach ridge vegetation need to be monitored. Jol (2004) suggested that if the vegetation is cleared from the beach, the existing blowouts along the beach ridge could become further destabilized. Therefore the blowouts need to be addressed before the beach is cleared to ensure the destabilization along the ridge does not spread.

Ecosystem health was an area of concern for many of the people surveyed. A local user of the area expressed the view that a considerable part of the ridge is privately owned and has been reworked to accommodate summer cottages and year round homes (Lehman pers. comm. 2004). Smith (2004) suggested that these homes be decommissioned. Other parts of the beach have had foot traffic and other disturbances that modify the natural vegetation. For the areas with relatively intact vegetation, access should be limited. These areas are represented by boreal species with mature conifers.

During the Questionnaire, a suggestion was made to provide more stairs down to the beach (Kinn pers. comm. 2004) and to move the pull-offs to the backside of the beach ridge, rather than at the top, to help control erosion (Jol, pers. comm. 2004). A further suggestion included increasing public education efforts. For example, existing signage was viewed as ineffective in controlling foot traffic (Kinn pers. comm. 2004).

\subsubsection{Public Involvement}

All people that were surveyed have identified local involvement as one of the key issues to implementing a successful management plan. Many people are unaware of the role of Alberta Community Development, Parks and Protected Areas Division in regards to the management of Devonshire Beach. The local stakeholders interviewed for this report expressed an interest in providing input into the management plan but were unaware of how this process would work.

During some of the interviews suggestions were made that any management plan should examine what was done for the Lesser Slave Lake Bird Observatory (LSLBO), which since its inception over a decade ago has gained worldwide recognition as Canada's northernmost migration monitoring station. Many lessons can be learned from local successes and it may be useful to implement a plan on a similar platform, but which is tailored to the needs of preserving the beach ridge along Devonshire Beach. Frank Fraser (2004) has indicated that two major planning documents that will become available in November 2004 may prove useful for developing a management plan for Devonshire Beach.

A proactive education outreach program has been deemed critical to the success in managing the beach for park values, recreation users and conservation measures ( $F$. Fraser 2004). The view often held by some of the local residents and many visitors to Lesser Slave Lake see the area as a beach and do not place value on the beach ridge as an important landscape feature worth preserving. When the area is viewed exclusively as a beach there is an expectation to 

have clean white sand devoid of vegetation. This view does not reflect the values appropriate to the ecosystem health of the site, to legislative classification, its status in a provincial park and general conservation principles (F.Fraser pers. comm. 2004).

A consultation strategy to develop a dialogue with the public as well as special interest groups has been suggested by J. Fraser (2004). In the past, the town of Slave Lake has used a list of key people involved socially, culturally and environmentally to help with local issues. This list of contacts could be used to encourage cooperation among stakeholders and to disseminate information regarding Devonshire Beach ecosystem management.

One suggestion for encouraging local involvement, including the local decision makers, was to conduct an education session that involved a field trip and a seminar ( $F$. Fraser pers. comm. 2004). These sessions would be designed to educate potential park users about the facts concerning the beach and beach ridge processes that occur along Devonshire Beach. Jol (2004) has suggested the field trip be for interested locals and that it would provide a forum for them to express their views. The field trip should include a knowledgeable person, either a researcher or academic, to lead the trip. The field trip should allow for discussion of the beach ridge issues, the offshore sand bars, the fore-dunes, and the north to south water currents. The field trip would ensure the community is well informed about the issues surrounding the Devonshire Beach region. The focus of the field trip should be on processes and not terminology as the dynamics of the beach are paramount.

For the seminar, the movie "Beach River of Sand" (part of the Earth Revealed Movie Series currently located at the University of Alberta library) could be a source of information. The movie illustrates offshore bar development of beach ridges and may be useful for the community to help understand the natural processes of beach ridge development. It could also illustrate how human influences affect a beach ridge, including the present weir on the river, its impacts on sand movement and the consequences.

All of the local people involved have offered to use their skills and knowledge of Devonshire Beach to help manage the area as best as possible. One of the local stakeholders wishes to encourage buffalo grazing in a portion of the land that abuts Devonshire Beach. He believes this would have been a natural use of the area in the past and believes this would be a draw for local tourism (Eben-Ebenau, pers. comm. 2004).

One of the local biology teachers offered to conduct a field trip of the area to show forest succession along the beach (Lehman pers. comm. 2004). F. Fraser (2004) has suggested that school children that are introduced to the natural values and key ecological roles the beach plays will allow them to be ambassadors to their parents and other adults.

The Chief of the Sawridge Indian Band has suggested that many of the elders of his community could be useful in providing accounts of historical vegetation regimes in the area. Additionally, the Band is interested in understanding the scientific principles behind the development of the beach ridge, in particular the impact of the weir and its potential influence on natural beach ridge processes. 



\subsection{Discussion}

\subsection{Research Protocol Critique and Study Limitations}

The approach taken for this study was to assess the significance of the beach ridge as a landform, to note the disturbance it has already incurred and to make recommendations for mitigation and management of the study area. The research protocol was guided by the Client to meet its needs for the development of an effective management plan. The tools used were threefold.

1. Literature review. The review was not exhaustive; however, many detailed reports on Lesser Slave Lake were incorporated in the report. Some provided information on ecologically significant areas, on vegetation communities, past reclamation efforts, beach ridge formation and history. The limiting factor of this part of the study was that much of the literature was not site specific for Devonshire Beach, but included the whole of Lesser Slave Lake. As a result, some gaps in information were identified. Furthermore, if more time was allotted a literature review of unpublished management plans from areas in Canada and the United States where beach ridges fall within protected parks would be useful for ideas on mitigation, conservation and management.

2. Field survey. The field survey captured one moment in time thus providing a current assessment of the disturbance levels affecting the beach ridge. It is possible that a longer-term survey might have resulted in slightly different conclusions and recommendations. Also, the survey only encompassed the lakeside of the beach ridge and disturbances have occurred on the east side of the ridge, which is outside of the study area. Also disturbances outside of the study area but within the watershed could be affecting the beach ridge and that was outside the scope of the study, but may provide valuable information.

3. Questionnaire. The surveys were not designed for any statistical manipulation, nor do they encompass all of the opinions and knowledge required for the design of a management plan. They provide a good starting point and fill in some of the information gaps required for the development of an effective management plan for Devonshire Beach.

Overall, the information in the report provides some direction for the proposed management plan and provides insight in to why the beach ridge is a significant landform. It also presents potential mitigative measures and recommendations for the management plan. 



\subsection{Beach Ridge Significance}

Factors influencing the formation of the beach ridge include: the size, alignment and location of the lake and the surrounding topography, the availability of source sand, climatic factors [seasonal and long term weather and wind patterns], lake water level, and floral and faunal patterns (BKA and Turner. 1996). All of these factors came into play during the formation of the beach ridge along Devonshire Beach and all must be considered in future management plans for the region in order to maintain this unique landform feature.

With only 22 occurrences of beach ridges in the province the beach ridge along Devonshire Beach is important as it is within a provincial park with road access. This feature is valued for road construction, and as sites for infrastructure, which in turn make it vulnerable to disturbance. With many beach ridges lost to resource extraction it stresses the need for conserving the beach ridge along Devonshire. The beach ridge along Devonshire Beach has active sand movement and it is not a relict formation unlike many of the beach ridges in the province.

The beach ridge at Devonshire Beach is a relatively intact formation that can easily be viewed by the public and provide a place to learn about the uniqueness of the feature.

\subsection{Beach Ridge Disturbance}

The overall condition of the beach ridge was assessed during the field survey of Devonshire Beach. Most of the active disturbances along the beach ridge are associated with road access, pull-offs and trails to the beach. Vegetation was for the most part well established and sand migration, which is a normal part of the beach ridge dynamics, was occurring. The site was floristically diverse with over 190 species of plants found along the $4.9 \mathrm{~km}$ stretch of beach ridge and beach. The area exhibited signs of wildlife use by a wide variety of species. The overall quality of the beach ridge led to the conclusion that it was suitable for preservation.

One of the most obvious man-made disturbances is the main gravel road that runs north/south along the crest of the beach ridge. This road ultimately influences the natural beach ridge dynamics by not allowing the ridge to prograde upward as the road is graded each year where migrating sand is redistributed. Removal of the road to mitigate the disturbance is not an easy decision. The local community, government officials, planners and academics that were interviewed agree that access needs to be maintained in some form. Part of the uniqueness of Devonshire Beach is that it represents an easily accessed, provincially significant landform. The current access allows individuals to easily view the landform and the dynamics currently at work in its maintenance. However, the road is detrimental to its development and is considered a major disturbance to the ridge.

Erosion of the ridge is readily apparent from trails that connect pull-offs situated along the main gravel road down to the beach. Along these uncontrolled trails vegetation is lost or destabilized and sand migration occurs often creating rills and gullies. Some measures are in place such as fencing and signage to limit the damage to the beach ridge, however erosion is still evident along the beach ridge that would likely not occur under undisturbed conditions. This erosion is the major disturbance that should be assessed for any future management plan.

Native vegetation such as Saskatoon berry (Prunus pensylvanica) and aspen (Populus tremuloides), and introduced species such as Cicer milk vetch (Astragalus cicer) and Russian wild rye (Elymus junceus) have been planted to control areas of active beach ridge movement. In some areas this has been completely successful (Lesko, 1974, BKA and Turner, 1996). Although sand stabilization through the planting of vegetation has previously been successful, care must be taken that introduced species are not out-competing and displacing native vegetation. In future reclamation efforts it may be possible to gradually replace some of the introduced species with 

native species to reconstruct traditional vegetation regimes. Also, fertilization was used on the beach ridge 30 years ago for reclamation (Lesko 1974) and this may not be an ideal option, which may impede the initial success of future reclamation projects if blowouts do occur.

The beach ridge formation is currently affected by local and external influences of wind and water. Consequently, changes to the flooding regimes and high water levels, in theory, would affect wave action, and the quantity and movement of sand available for beach ridge formation and maintenance. However, these changes to the water levels and wave action have not been studied, so it is unknown how the change in water levels have actually affected beach and beach ridge processes. The controlled water levels may also potentially affect vegetation that grows on the shoreline, as the weir may reduce the scouring effect of the lake if high water levels are controlled.

Lake and wind processes are actively involved in the formation of the beach, fore-dune and ridge area of the beach. These features have been modified by human activity in order to balance the objectives of meeting the needs of people, the environment and the economy of the area. A decision has to be made on whether natural processes or preservation of the beach ridge in its present state is the top priority for the beach ridge.

\subsection{The Role of Vegetation on the Beach and Ridge}

The formation of the beach and the associated beach ridge along Devonshire are inextricably linked with the vegetation. According to Smith (2004), the formation of the ridge begins, willows then stabilize it and vertical accumulation occurs. The development of the ridge and the vegetation that grows on it is a symbiotic relationship. Eventually, if undisturbed, another beach ridge will form. The source of sand is from the beach. Occasional high water levels prevent vegetation from encroaching onto beaches (Bradley 1980); this ultimately creates open areas of sand that become windblown and transported into the fore-dune and beach ridge areas. As land progrades towards the beach another beach ridge will form, however this process of beach ridge initiation is not well understood (Smith, pers. comm. 2004).

Currently there are no facts or evidence to quantify the effects of disturbance, natural or human on the development of the beach ridge (Smith, pers. comm., 2004). The beach ridge formation builds up and vegetation establishment helps to maintain the beach ridge, but it can be easily destabilized resulting in a blow out. Two blowouts have previously been stabilized along the ridge, but further blowouts may occur due to fires, animal trails and human activity.

Smith (2004) suggested that human activity has changed the beach ridge and that the vegetation should be left alone to let nature take care of itself. A weir constructed in the lake outlet may have affected the beach ridge, as the necessary water level changes are now somewhat controlled allowing vegetation to take hold along the beach. However, it is not necessarily known whether this affects the development of the beach ridge. Geomorphic processes need to run their natural course in order to maintain the beach ridge, leaving the vegetation as it is, is an integral part of the process (Smith, pers. comm. 2004). Jol (2004) has suggested that if the vegetation were removed from the beach area the blowouts on the ridge would have to be stabilized first, as they would be vulnerable to greater erosion once the beach area was cleared.

Smith (2004) has suggested that the beach ridge be left as it is at this time. If vegetation such as the willows is removed from the beach a chain reaction could start, and once destabilized it is expensive and difficult to fix. He believes that one cannot improve the beach by removing the vegetation. After interference the area could become degraded rather than enhanced. $\mathrm{He}$ also feels that the beach ridge is very vulnerable due to the current drought conditions. During dry periods is not the appropriate time to destabilize the vegetation. However, conflicting views by others survey respondents exist. Some stakeholders feel the vegetation on the beach is not 

natural and that a beach clean up is necessary to allow the natural processes of beach ridge development to continue.

Currently 350 metres of shoreline are groomed along Devonshire Beach. Some interest has been expressed in extending the area to be groomed to allow for a larger area to have ideal sandy beach for recreational uses. Part of the conflict with this beach grooming is the occurrence of a rare willow (Salix sitchensis) along the beach. Currently the provincial population of this particular willow is only found along Lesser Slave Lake with the only other population found in 1968 near Whitecourt. Also, willows are vital for the progradation or build-up of the beach ridge. Willows are important for stabilizing sand movement and controlling erosion. However, with the construction of a weir in 1983, some local land users and academics researching in the area feel that the scouring affect of the lake has been minimized by the controlled lake level allowing vegetation to encroach on the beach. Dr. Jol (2004) has suggested that this vegetation encroachment along the beach may tie up much of the free sand needed to build up the beach ridge, however more research would be needed to verify the observations. 



\subsection{Recommendations}

\subsection{Conservation and Management}

Four options, with regards to recommendations on conservation and management of the beach ridge, have been suggested. All of the options made are geared towards maintaining or enhancing the beach ridge landform. No options were made that would negatively alter the landform or cause environmental degradation. Options have been presented, as any decision on the best way to manage Devonshire beach will be dependent on management goals and associated funding.

1. No Mediation. Develop a management plan that has no direct intervention and allows for nature to take its natural course in the area.

2. Low Mediation. Maintains the status quo of the area. Current management, in terms of the beach area that is groomed, the road, pull-offs, parking lots, trails, boardwalks, snow fences and picnic areas are maintained.

3. Moderate Mediation. This option allows for some of the disturbances to be mitigated, particularly in regards to the current erosion on the beach ridge. The ungroomed portions of the beach would be partially scoured to control encroaching vegetation and extend the groomed beach for recreational purposes.

4. High Mediation. This option allows for extensive rehabilitation of the beach ridge. This would be costly, but the main gravel road and houses along Devonshire Beach would be decommissioned and a moveable weir installed to allow for greater lake level fluctuations.

No Mediation. A "No management" approach may prove ideal for nature to take care of itself. With this recommendation the park will be left to manage itself. Minor monitoring would be essential to ensure that degradation does not occur from human activity that causes damage to the natural environment and processes. This may require fines to be levied for abusers of the area.

Pros: This option allows for natural processes to occur without any human interference. Vegetation succession and landform processes take precedence over recreation and access needs.

Cons: This option would not allow for the maintenance of access roads and pull-offs on the beach ridge, as they would be left for nature to manage. Furthermore no grooming would take place on the beach, which may impact recreation use.

Low Mediation. This recommendation would allow for the status quo to be maintained. Currently the park has a large paved parking lot, a gravel road along the ridge, and a series of pull-offs along the ridge, boardwalks, and fencing to control sand movement. This option would maintain the current access and some of the erosion would be controlled. For example, fences have been constructed along the beach and significant sand accumulations have been noted. These types of successful mitigative measures would be maintained along areas of the beach ridge where erosion has caused rills and gullying, particularly downslope from the side pull-offs along the road (Figure 12). 



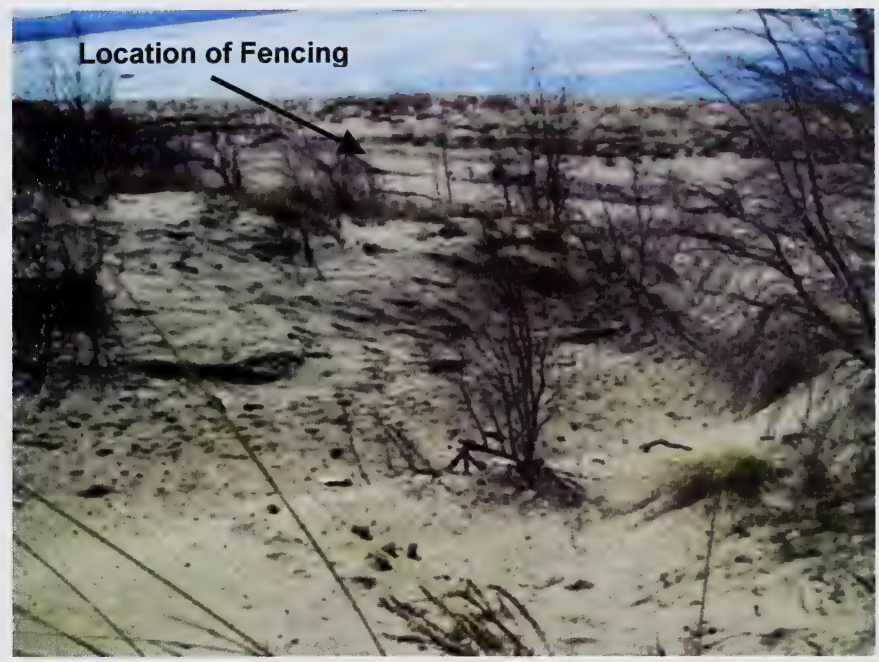

Figure 12. Use of fencing to capture sand and control erosion.

Pros: Currently the beach is a popular recreation spot and allows for great access to view the entire length of the beach ridge.

Cons: Erosion is still occurring along uncontrolled access trails. Vegetation encroachment would still pose a problem for people wanting the areas of cleared beach extended. This option does not encourage further recreational use. The beach ridge crest would still be impacted as the road would be plowed and graded each year to clear migrating sand.

Moderate Mediation. Historically, a number of steps have been taken to control the drifting sand along the beach ridge. These mitigative measures include fences, boardwalks, stairs and revegetation. Using this option the erosion control measures would be further encouraged and developed along the entire length of the beach. For example, boardwalks have been constructed along a portion of the south end of the park. These boardwalks are useful, however each year they often become covered by drifting sand (Figure 13). Jol (2004) recommended duplicating measures undertaken in similar coastal situations in Washington. There, boardwalks are suspended to let natural vegetation grow underneath, while still allowing for access to the beach. $\mathrm{He}$ also recommended that more boardwalks could be built along the beach. 



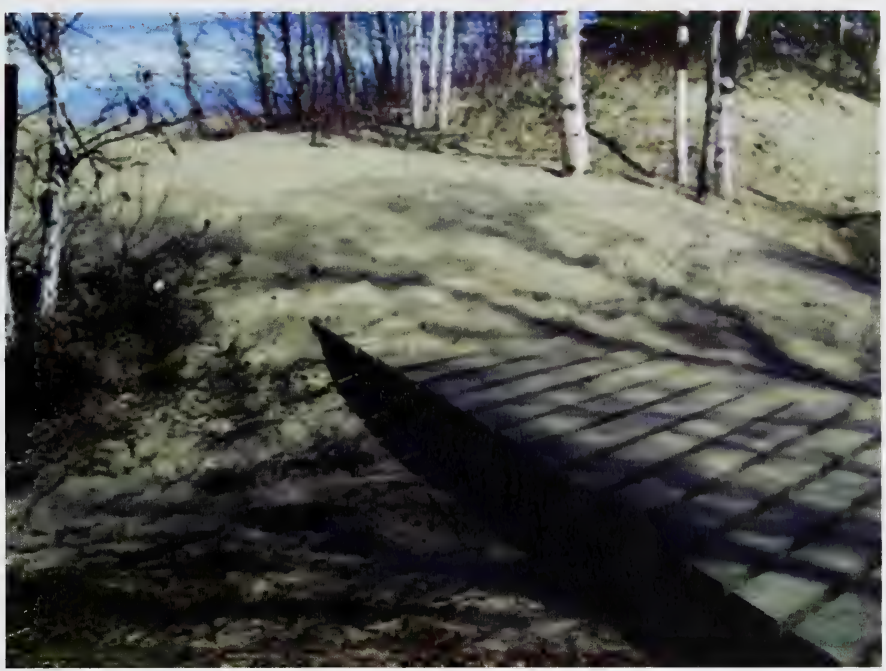

Figure 13. Boardwalk with drifting sand.

A series of stairs or ramps would be constructed from existing access points along the ridge top to the beach to filter foot traffic to controlled access points to reduce erosion. In areas of natural disturbance, revegetation using native species could be used to control the erosion. The road running along the length of the beach ridge would be gated and used for foot traffic and vehicle traffic of park personnel and cabin owners. Additional parking would be created along the backside of the ridge to account for lost parking on the crest of the ridge.

Grooming of the beach would be extended, however the population of rare willow would have to be excluded and thus grooming may only encompass a narrow band along the shoreline. A portion of the north end of the shoreline would remain ungroomed with viewing platforms for people to observe the vegetation and wildlife that occur on the vegetated portions of the beach.

Pros: The extension of the grooming of the beach would be beneficial for recreation. The crest of the ridge would be allowed to recover from erosion, as access would be controlled along the ridge top.

Cons: Access along the ridge would be limited and the parking areas would not be as close in proximity. Extra expense would be incurred installing access gates, additional parking, building stairs and ramps as well as platforms and suspended boardwalks. The appearance of additional man-made structures along the beach may appear unsightly to more naturalist minded people. The backside of the ridge does have important habitat for wildlife and a portion of that would be lost to the parking lot construction.

High Mediation. Devonshire Beach represents a unique area. Management at this level would involve extensive rehabilitation of the area and provide additional recreational use to increase tourism to the area.

The gravel road that runs the length of the ridge and the associated pull-offs would be decommissioned and revegetated with natural species. Parking would be limited to either end of the ridge, restricting access to two points into the park. The two residences along the beach ridge would be expropriated and the sites rehabilitated. This plan would allow for further boardwalks and access to be built to accommodate recreational uses, but would be limited in 

areas prone to erosion along the beach ridge. Trail systems along the backside of the ridge would be built and extended for recreational and educational purposes.

The park would undergo vegetation rehabilitation by both a weed control program to remove noxious weeds and the program would promote the removal of introduced species and replace them with ones that would naturally occur in the area.

In areas where lake incursion should normally occur the vegetation would be removed to that level to account for the construction of the weir. If finances were not limiting, a moveable weir could be constructed rather than an immovable weir to allow for some lake level fluctuations that would mimic natural conditions, but could still control very large flood events. Any changes to the weir would not be possible by Alberta Community Development, Parks and Protected Areas Division but would have to involve Alberta Environment, the Department of Fisheries and Oceans and other related provincial and federal agencies.

At one end of the beach ridge a small concession stand for tourism and a venue to learn about the beach ridge could be constructed to allow for observation of the landform, a facility for education on the attributes of the local area, one that could be used for housing park staff and a food service center for tourists.

Pros: The options at this level allow for some of the beach ridge to return to a more natural state along the ridgeline. The natural vegetation would be enhanced and invasive and introduced species would be discouraged. Erosion would be controlled along the ridge with reduced foot traffic and most of the noticeable disturbances such as cabins, removed. Tourism in the area may benefit by the increased beach that is groomed, as well as increased services in the form of the concession venue and trails.

Cons: Disturbance will occur on either end of the beach ridge to increase parking capacity and the construction of an interpretive facility. Management at this level is quite costly and involves a long-term commitment to fulfill all of the recommendations. Management along the beach would be a visible presence and some of the naturalness would be lost at Devonshire Beach.

\subsection{Further Study}

Two main studies were suggested for Lesser Slave Lake Provincial Park, specifically related to the beach ridges that already exist and the beach ridge that is currently being formed.

One suggestion for further investigation is to complete a biophysical inventory of the beach ridges on the east side of Highway 88 . Smith (2004) suggests that they may be significant landforms worth preserving as an example of ancient beach ridges. The ancient beach ridges are different from the current ridge along Devonshire Beach because lake dynamics have changed from historic times. They are floristically and geomorphologically different, and possibly worth preserving as significant features as well.

Further concern for monitoring the impacts of multiple land uses arose from some of the local stakeholders who were interviewed. They expressed concern about an immovable weir and channel straightening along Lesser Slave River, which is the single outlet of Lesser Slave Lake.

A historical study on the impacts of the weir built in 1983 on the beach ridge landform and associated vegetation may be useful to provide information on vegetation management and beach ridge progradation over time. Any studies that Alberta Community Development, Parks and Protected Areas Division would have to be in co-operation with Alberta Environment and the Department of Fisheries and Oceans. 



\subsection{Monitoring of Disturbances}

Disturbances to Devonshire Beach are difficult to quantify. Lesser Slave Lake is an extensive area that receives input from four major inlets: South Heart, Driftpile River, Swan River and Assineau River. The drainage basin is approximately $12,400 \mathrm{~km}^{2}$ or 11 times greater than that of the lake (Mitchell and Prepas 1990, Saxena and Bentz 1993). Adjacent areas undergoing resource exploitation by agriculture, oil and gas and forestry interests could potentially be impacting Lesser Slave Lake and subsequently, Devonshire Beach. It may be important to monitor surrounding land uses and assess how the beach is being influenced.

Both Smith and Jol (2004) suggested that a second beach ridge is currently being formed offshore. If a function of the new management plan is to help preserve the processes required in the formation of beach ridges, it is essential to monitor the beach ridge that is currently developing. This would help to ensure that natural processes are continuing and that management efforts are helping, not hindering beach ridge formation. 



\subsection{Conclusion}

Devonshire Beach is a unique place within Alberta and one of the integral components of Lesser Slave Lake Provincial Park is the beach ridge. Although the beach ridge has been subjected to a number of human disturbances (over the years) that may be difficult to reverse, the beach ridge is still relatively intact and is worthy of preservation. The beach ridge represents not only a rare and unique landform both provincially and regionally, it has historical significance to many people of the Lesser Slave Lake region.

A debate exists on what measures need to be taken to preserve the beach ridge. The area is popular for tourism and recreation, activities that may conflict with preservation of the conditions that promote beach ridge formation. All stakeholders interviewed expressed a desire to keep the naturalness of the area intact, and to discourage extensive development as has occurred in other areas such as Sylvan Lake.

When developing an effective management plan a clear mandate is needed. The decision makers should ensure that all people influenced by the plan have a clear understanding of what is being decided upon and why certain decisions were made. All interested stakeholders should have input into the decision making process. 



\subsection{References}

Alberta Environment. 1998. Special Features in Alberta - Proposed Framework for Site Identification and Initial Evaluation of Potential Special Feature Sites. Edmonton, Alberta.

Alberta Environmental Protection. 1993. Lesser Slave Lake Regulation Project - Information Update. July 1993.

Alberta Provincial Parks, n.d. Lesser Slave Lake Provincial Park - Park History. Parks Planning, Edmonton.

Bentz, J. and A. Saxena. 1993. Significant Ecological Features Inventory of the Lesser Slave Lake Integrated Resource Planning Area. Geowest Environmental Consultants.

Bradley, C. 1980. Lesser Slave Lake Provincial Park Biophysical Inventory and Resource Assessment. Resource Assessment and Management Section, Alberta Provincial Parks.

Bradley, C. and S. Loomis 1978. Lesser Slave Lake Regulations Study - A Brief Summary of the Concerns of the Provincial Parks Division.

Butler Krebbes \& Associates and N.A. Turner. 1996. Big Lake Discovery Centre at Devonshire Beach, Lesser Slave Lake Provincial Park. Prepared for Big Lake Discovery Centre Project Steering Committee.

Chabaylo, R.M. and S. Knight. 1997. Ecological Assessment of the Lesser Slave Lake Shoreline. RMC Environmental Services and Strategic Management and Evaluation Branch, Alberta Environmental Protection.

Clark, A.G. 1998. The Lesser Slave Lake Dune Ridge Barrier Complex, North Central Alberta: Depositional Processes, Paleogeography and Paleoclimate. A Thesis Submitted to the Faculty of Graduate Studies in Partial Fulfillment of the Requirements for the Degree of Master of Science. Department of Geography. Calgary, Alberta. August, 1998.

Doberstein, A. 1978. Habitat classification survey of a portion of the Lesser Slave Lake basin. Unpublished report. Canadian Wildlife Service: for Alberta Environment, Edmonton.

Ealy, D. 1979. Lesser Slave Lake Regulation Environmental Impact Assessment - Vegetation and Wildlife Impact Studies.

Greenlee, G. 1973. Lesser Slave Lake Provincial Park Soil Survey and Interpretation for Recreational Use.

Howitt, R.W. and G.M. Greenlee. 1981. Addendum to Soil Survey of Lesser Slave Lake Provincial Park and Interpretation for Recreational Use. Alberta Research Council Report.

Lesko, G.L. 1974. Species suitability for beach ridge reclamation at Lesser Slave Lake, Alberta. Environment Canada, Forestry Service. Information Report NOR-X-86.

Lombard North Planning Ltd. 1972. Lesser Slave Lake Provincial Park Master Plan Study.

Mitchell, P. and E. Prepas. 1990. Atlas of Alberta Lakes. University of Alberta Lakes, Edmonton, Alberta. 

Parker, S.P. II. 1997. McGraw-Hill dictionary of Earth Science. McGraw Hill Inc.

Sawyer, G. 1981. A History of Lesser Slave Lake.

http://www.epa.qld.gov.au/publications/p00078aa.pdf/Formation_of_sand_beach_ridges_and_ch eniers.pdf

http://www.epa.qld.gov.au/publications/p00080aa.pdf/Formation_of_blowouts_parabolic_dunes_ ow_dunes_and_mobile_sandsheets.pdf

Smith, D. G. 1987. Landforms of Alberta interpreted from airphotos and satellite imagery (page 68). Edmonton: Alberta Environment, Alberta Remote Sensing Center.

\section{Personal Communications}

Eben Ebenau, R. 2004. Mr. Eben Ebenau is a current stakeholder along Devonshire Beach. His current intent is to keep the area natural and provide it as a natural wintering ground for his herd of buffalo. The area is not fenced yet, but it is a good landuse as buffalo would historically graze the area. Roland's father was an original homesteader in the area of Slave Lake. His father was a trapper, guide and outfitter.

Fraser, F. 2004. Mr. Fraser currently works for Alberta Community Development, Parks and Protected Areas Division. He is actively involved with Lesser Slave Lake Bird Observatory and along with many others helped establish it as Canada's northernmost migration monitoring station.

Fraser, J.A. 2004. Ms. Fraser was on the steering committee for the Discovery Centre and Employed as a Planner for the Town of Slave Lake (Municipal district for Slave Lake) for six years between mid 1991 to mid 1998.

Jol, H. 2004. Dr. Jol has worked at Devonshire Beach studying the beach ridge and has studied the back ridges and completed offshore work. His findings were published in 1993 for the work he completed in 1992 at Devonshire Beach. Dr. Jol completed his PhD on lacustrine coastal landforms. He recently completed a study examining coastal features on Lake Athabasca. Dr. Jol's experience is extensive and he has studied beach ridges and other coastal landforms in Northern Carolina, Florida, Texas, Oregon, Washington, Utah and California.

Kihn, G. 2004. Mr. Kihn is a conservation officer and had previously worked at Slave Lake for 13 years.

Lehman, A. 2004. Mr. Lehman is a local of Slave Lake. He has used Devonshire beach for interpretive tours for high school biology classes to teach the concept of vegetation succession.

Smith, D. 2004. Dr. Smith is a professor in the Department of Geography at the University of Calgary. He has conducted field research in geomorphology and sedimentology across North America. Dr Smith specializes in sedimentology and geomorphology. His current research is in reconstructing paleo and modern fluvial, deltaic, coastal and tidal estuarine depositional environments.

Twinn. R. 2004. Mr. Twinn is the current chief of the Sawridge Indian Band. The Sawridge reserves cover 5296 acres and are accessible by road, rail, and water. These first nations people have long, historical links to the area of Devonshire Beach. 

Appendix A 




\section{Significance evaluation of the Lesser Slave Lake Provincial Park Extension - Devonshire Beach} (Adapted from AE 1998).

\begin{tabular}{|c|c|c|c|c|c|c|c|c|c|c|c|}
\hline \multicolumn{4}{|c|}{ Selection Factor $(\mathrm{s})^{\top}$} & \multicolumn{7}{|c|}{ Evaluation Scores } & \multirow{2}{*}{$\begin{array}{l}\text { Priority } \\
\text { Level }\end{array}$} \\
\hline Rare & Outstanding & $\begin{array}{l}\text { At } \\
\text { Risk }\end{array}$ & Assemblage & ERank $^{2}$ & $\mathrm{EnSig}^{3}$ & $\# \mathrm{SE}^{4}$ & $\#$ SEG $^{5}$ & Evol $^{6}$ & Threat $^{7}$ & PARep $^{8}$ & \\
\hline & $Y$ & & & 1 & 3 & 1 & 1 & 2 & 4 & 4 & 3 \\
\hline
\end{tabular}

1. Selection Criteria:

- $\quad$ Priority Rare Elements - Includes one or more elements with five or fewer known occurrences provincially or 100 or fewer occurrences globally

- $\quad$ Outstanding Elements - Includes one or more elements that are recognized as outstanding examples in a provincial, national or international context. This may include noteworthy landforms or vegetation types or sites with seasonal concentrations of vertebrate animals (e.g. internationally recognized shorebird staging areas)

- Elements at Risk - Includes one or more elements considered at risk due to being restricted to a small portion of their former range or extent

- Assemblage of Elements - Areas with four or more elements considered of special conservation

2. Rarity: Rank of Special Elements

- rank is indicator of rarity based on the number of known occurrences both provincially and globally

5 - 1 element occurrence in Alberta and uncommon globally

$4-1-5$ element occurrences in Alberta

$3-6-20$ element occurrences in Alberta and uncommon globally

2-6-20 element occurrences in Alberta

1 - >20 element occurrences in Alberta

3. Environmental Significance

- evaluation of the conservation profile, noteworthiness or outstanding nature of a special feature and the special elements contained within it

5 - International Significance

4 - National Significance

3 - Outstanding Provincial Significance

2 - Provincial Significance

1 - Regional Significance

4. Diversity - Number of Special Elements

- the number of special elements within a special feature polygon is an indicator of environmental diversity

5 - $>10$ elements

4 - 5-10 elements

3-3-4 elements

$2-2$ elements

$1-1$ element

5. Diversity - Number of Special Element Groups

- the number of special element groups (i.e. landform, vegetation community, vascular plant, non-vascular plant and vertebrate) within a special feature polygon is an indicator of environmental diversity

5 - 5 element groups

$4-4$ element groups

$3-3$ element groups

$2-2$ element groups

1 - 1 element group

6. Evolutionary Significance

- provides a genetic perspective incorporated into the evaluation of special biological elements on the basis of evolutionary significance (i.e. endemic plants)

- based on Natural Regions and Subregions classification of Alberta

5 - Dry Mixedgrass, Peace River Parkland, Southern Montane (Crowsnest Pass, Porcupine Hills and Cypress Hills) and Athabasca Plain

4 - Central Parkland, Subarctic and Northern Montane

3 - Foothills Natural Region, Foothills Fescue, Mixedgrass and Northern Fescue

2 - Boreal Forest Natural Region and Kazan Upland

$1-N / A$ 

7. Degree of Threat

- an evaluation of the degree of threat to ecological integrity based on an assessment of the degree of humancaused disturbances that have or are expected to pose threats to biodiversity and ecological processes within natural subregions

- based on Natural Regions and Subregions classification of Alberta

5 - Mixedgrass, Northern Fescue, Central Parkland and Peace River Parkland

4 - Foothills Fescue, Foothills Parkland, Lower Foothills, Montane and Dry Mixedwood

3 - Dry Mixedgrass, Upper Foothills, Subalpine, Central Mixedwood and Boreal Highlands

2 - Wetland Mixedwood, Peace River Lowlands, Subarctic, Athabasca Plain

1 - Alpine and Kazan Upland

8. Representation of Special Elements in Protected Areas

- a measure of the degree of protection already provided elements found within special feature polygons

For elements with 5 or fewer occurrences in Alberta

$5-0$ occurrences in protected areas

$4-1-3$ occurrences in protected areas

$3-4$ occurrences in protected areas

$2-N / A$

1-N/A

For elements with more than 5 occurrences in Alberta

5 - 0 occurrences in protected areas

$4-1-24 \%$ of occurrences in protected areas

$3-25-49 \%$ of occurrences in protected areas

$2-50-74 \%$ of occurrences in protected areas

$1-\geq 75 \%$ occurrences in protected areas

Protected area representation scores of all elements in the special feature polygon were then evaluated and the polygon given a combined score as follows:

$5-\geq 50 \%$ or elements with a score of 5

$4-\geq 50 \%$ or elements with a score of 4 to 5

$3-\geq 50 \%$ or elements with a score of 3 to 5 or 3 to 1

$2-\geq 50 \%$ or elements with a score of 2 to 1

$1-\geq 50 \%$ or elements with a score of 1 

